\title{
Effects of regulating international trade on firms and workers
}

\section{The benefits of trade regulation increase when workers are mobile}

Keywords: regulation, international trade, adjustment costs, tariffs

\section{ELEVATOR PITCH}

Economists have shown that international trade increases economic growth, with trade liberalization and integration having characterized the last 50 years. While trade can increase national welfare, recent estimates from both developed and developing countries show that labor market adjustment costs matter. Regulating trade, defined as adding or removing tariffs and other trade barriers, is not the best way to help lower-income workers who suffer from trade-induced losses. Policies that reduce adjustment costs may increase aggregate welfare more than regulating trade flows does.

\section{KEY FINDINGS}

\section{Pros}

๑ Trade increases national welfare by lowering prices for consumers, adding product variety, and contributing to economic growth.

๑ If part of a selective and proactive industrial policy, regulating international trade can help developing countries support exporting firms and workers.

$\oplus$ Reducing adjustment costs can increase the welfare gains from trade in both developed and developing countries.

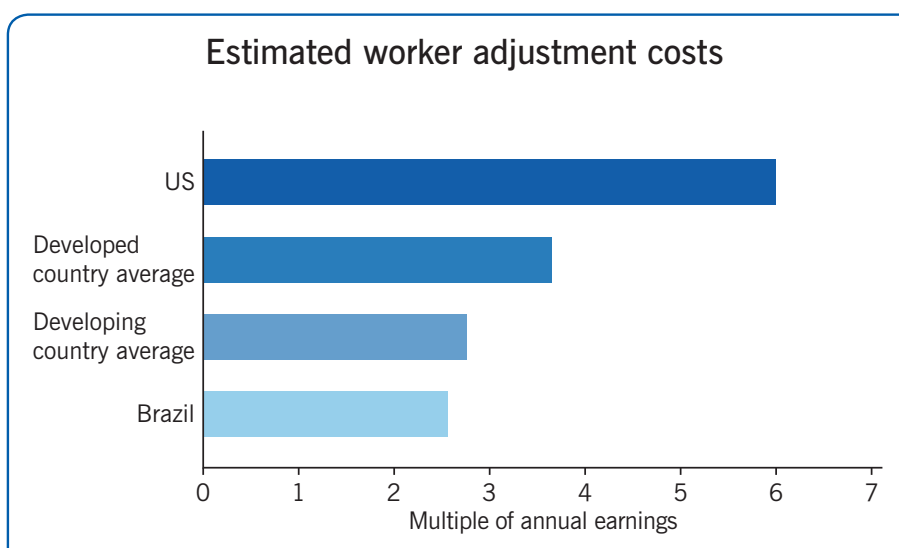

Source: Author's own compilation. Estimates taken from [1], [2], and [3].

\section{Cons}

- Trade liberalization leads to reallocation of workers and resources across sectors and therefore imposes significant adjustment costs on workers.

- Even if trade liberalization increases national welfare, the costs can be highly concentrated geographically.

- Regulating international trade to recover lost jobs may not be effective because mobility costs are significant.

- Failure to address concentrated losses can undermine popular support for trade.

\section{AUTHOR'S MAIN MESSAGE}

While trade increases national welfare, its liberalization can impose significant and concentrated costs on workers. These costs are often born disproportionately by certain segments of society, which has created a groundswell of anti-globalization in many countries, as evidenced by the UK's exit from the EU (Brexit) and the US withdrawing from or renegotiating key free trade agreements. Reducing adjustment costs would be a more effective policy to boost employment than trying to restrict trade. In developing countries, however, carefully managed trade regulation can play a key role in supporting firms and workers in ways that contribute to economic growth. 


\section{MOTIVATION}

Foryears, economists have been nearly unanimous in their support for free trade. Although it has been known since at least 1941 that trade brings winners and losers (the StolperSamuelson Theorem), for the most part, the assumption that the gains outweighed the losses dominated both economic and political thought. As a result, both developed and developing countries have pursued policies to foster international trade. Since World War II, trade barriers have fallen dramatically, while trade and global output have risen significantly.

Recently, however, support for trade liberalization has been falling, as nationalism has risen in both the US and Europe. The US has pulled out of the Trans-Pacific Partnership (TPP), North America is renegotiating the North American Free Trade Agreement (NAFTA), and the UK voted to leave the EU (so-called "Brexit"). Rising backlash against globalization motivated economists to better understand the sources of this resentment. Regulating international trade has emerged as a political response to public discontent: calls for raising tariffs and pulling out of trade agreements are becoming more common. One reason for the negative public reaction is that adjustment costs are significant. Adjustment costs, such as those associated with moving to a new city, finding and starting a job in a new industry, or having to learn new skills, keep workers from moving from shrinking industries to growing industries. Understanding how workers and industries adjust to globalization is critically important when crafting a policy response to the costs imposed by international trade in both developed and developing countries.

\section{DISCUSSION OF PROS AND CONS}

Most 20th-century trade theory takes a long-term view of trade liberalization and assumes that workers can move costlessly between industries. While a study from the 1990s illustrates the importance of adjustment costs at the firm level [4], these costs have only recently begun to feature prominently in studies of trade liberalization in both developed and developing countries. The implications for policy are significant because the traditional calculation of the costs and benefits of trade gives an edge to the benefits; but, it does not include adjustment costs. Adding these costs could suggest, on the one hand, that the net benefits of trade are negative. On the other hand, the importance of adjustment costs suggests that policy should be directed at alleviating these costs rather than trying to regulate trade in order to help workers who lose out from it.

\section{Trade, welfare, and growth}

Two of the main benefits of trade are generally considered to be economic growth and consumer gains due to lower prices of imported products. The early neoclassical trade models show that the main gains from free trade can be attributed to the latter. While some win and some lose, the models almost always show that net welfare gains are positive. Recent studies have also shown other important dimensions of welfare gains. For example, in addition to falling prices from cheaper imports, increasing the variety of products to consumers and as inputs into production both increase national welfare.

In addition to the welfare gains from a wider variety of cheaper goods, international trade is often associated with economic growth. The positive relationship between trade and 
growth has been strongly supported during the 2000s, with the experiences of China, Latin America, and several African countries serving as anecdotal examples.

Of course, the fact that trade is related to growth does not necessarily mean that changes in trade policy, such as trade liberalization, bring growth automatically. For instance, many critics of trade are quick to point out that growth in Latin America was slower during the years immediately following trade liberalization (roughly the 1990s) than during the closed-economy period (roughly the 1950s-1970s). While it is important to note that the 2000s were a period of trade-led growth, the fact that there was a very significant lag between trade liberalization and trade-led growth implies a substantial adjustment period. Trade liberalization causes resources to reallocate across sectors, which takes time. One reason for this is that adjustment costs matter.

\section{Types of adjustment costs}

Recently, the proliferation of research articles that incorporate adjustment costs into models of trade liberalization has inspired several literature reviews. However, these studies rarely, if ever, clarify the distinction between firm-specific and worker-specific adjustment costs. This is a crucial oversight, as the two costs are distinct and have different welfare and policy implications.

When adjusting employment, firms incur several costs, including, but not limited to, those for training workers, search costs, and separation payments. The above-mentioned study (and other related papers) provides the foundation for understanding such firm-level adjustment costs [4]. Firms have to pay a given level of costs that does not depend on the number of workers being hired (e.g. placing a job announcement for one worker costs the same as an announcement for ten workers), and if the shock is large enough, firms will adjust employment very quickly. They can also be quite large but vary across countries. A 2002 study finds that firm-level adjustment costs are an order of magnitude smaller in Mexico than in the US [5]. Firm adjustment costs have also been found to be asymmetric and to interact with worker behavior [4]. For example, voluntary quits rise during boom times and fall during recessions. This suggests that it is important to also consider worker-level adjustment costs.

Most recent studies of trade and adjustment focus on worker-level adjustment costs. Workers incur the costs of searching for new jobs, learning about new technologies, loss of firm and industry-specific human capital, and mobility (e.g. if they have to change location). As such, moving between industries can be quite costly. Figure 1 summarizes some recent estimates of worker-level mobility costs across a range of developing countries and shows that these costs are particularly significant [2]. As a result, workers tend to resist moving (either location or industry), even when moving would result in higher wages.

Together, firm- and worker-level adjustment costs suggest that a change in trade regulation may induce very costly adjustment and localized wage and employment effects. That is, workers who live in a metropolitan area that produces import-competing products will experience falling wages and falling employment from import competition, while otherwise identical workers who live in an area that instead produces exported goods may not experience these negative effects and perhaps would experience rising wages. Emerging research from both developed and developing countries is documenting exactly these kinds of localized effects. 
Figure 1. Regional worker-level adjustment cost estimates

\begin{tabular}{lc}
\hline Region & Mobility cost \\
\hline North America & 2.21 \\
Western Europe & 2.61 \\
Latin America \& Caribbean & 3.23 \\
East Asia \& Pacific & 3.46 \\
Middle East \& North Africa & 3.59 \\
South Asia & 3.88 \\
Eastern Europe \& Central Asia & 3.95 \\
Sub-Saharan Africa & 4.00 \\
\hline
\end{tabular}

Note: Mobility costs are multiples of a given worker's annual income.

Source: Based on data in Artuc, E., D. Lederman, and G. Porto. "A mapping of labor mobility costs in the developing world." Journal of International Economics 95:1 (2015): 28-41 [2].

\section{Experience in developed countries}

Several recent studies focus on the localized effects of Chinese trade on developed countries. They do so for two reasons. The first is that production tends to be geographically concentrated. That is, production of different goods is concentrated in different areas of a country. When production is highly localized, lower-cost imports of a particular good will benefit consumers of that good nationwide; however, areas with a high concentration of producers competing with these imports will experience a fall in employment.

The second reason is that workers tend to resist moving between regions because moving costs are high. If workers incur significant relocation costs, the effects of trade liberalization will be highly localized. Workers who lose their jobs in a particular region will try to "wait it out," shift to another sector in their region, or seek work elsewhere. All three of these options imply that adjustment can be slow and costly.

A growing body of research shows that the effects of trade are, indeed, highly regionalized. German regions specializing in export-oriented industries experienced employment gains and lower unemployment as trade between Germany, China, and Eastern Europe rose over the 1988-2008 period. Regions specializing in import-competing industries, however, saw substantial job losses, for example, in the manufacturing sector and beyond. Another study finds significant adverse effects on US local labor markets, even though the rise of China created both import penetration and new export opportunities [6]. Others have put the estimates of US jobs lost due to trade with China at nearly one million. However, ten years after the rise of Chinese import competition, the areas adversely affected by trade had very similar populations. That is, people did not want to relocate, even after nearly a decade of import competition. Occupational mobility can be protracted and costly, especially when workers are older or uneducated and need to switch occupations.

The lack of mobility is not always negative, of course. Workers in areas with exporting industries can benefit. For example, US labor markets such as California experience 
net benefits because access to lower-cost inputs (from other US states and also from China) help reduce production costs. Other developed countries that are more open to trade, such as Australia, experience many of the same benefits and therefore experience significant welfare gains from trade with China.

\section{Evidence from developing countries}

Developing countries are also vulnerable to the effects of trade liberalization, which can be highly localized and quite negative. When workers live in areas characterized by an industry that has its previously protective trade regulations removed, they can experience significant losses.

For example, recent studies from Brazil suggest that worker adjustment in importcompeting industries after trade liberalization was especially costly. Brazil liberalized in the early 1990s and the reductions in tariffs induced significant displacement. Twenty years after liberalization, the estimated effects were three times larger than after ten years, indicating that the effects can be very long-lasting and can worsen over time. Workers who separated from their jobs took years to find a new job in a new industry. Perhaps not surprisingly, workers often spend long intervals in the informal sector. A 2014 study estimates that the median cost of worker mobility (again referring to, for example, physical mobility, learning or transferring skills, and job search) in Brazil ranges from 1.4 to 2.7 times annual average wages [3]. Furthermore, results show that workers' experience is imperfectly transferable across sectors, adding another barrier to labor mobility.

Workers in India faced similar challenges. India liberalized international trade in 1991 by cutting average tariff rates by more than half. Other regulations, such as licensing requirements and quantitative restrictions on imports, were also significantly reduced. District-specific trade shocks affected rural districts with concentrated industries that were more exposed to import competition; the impacted areas experienced increases in poverty and inequality. Not surprisingly, these results suggest that labor mobility is quite limited.

In the first few years following trade liberalization in Latin America, several studies pointed to the rise in wage inequality as evidence that the neoclassical trade theories were "dead." This is because it was assumed that, as labor-abundant countries, trade liberalization would have been accompanied by falling inequality in Latin America, whereas inequality actually rose in the short term. In the longer-term, however, Latin America experienced a consistent and sustained fall in wage inequality. For example, a 2004 study illustrates the short-term rise and subsequent long-term fall in Mexican inequality [7]. Indeed, falling inequality, falling poverty, and rising demand for less-skilled workers all characterized the 2000-2013 period throughout Latin America. Many studies credit rising exports to China for these positive effects, although few of the trade studies discussed here formally illustrate this link. The main lesson from Latin America, at least, is that studies of the longer-term effects of trade should focus on export growth as well as rising import competition.

A few studies in developing countries have begun to focus on exports and the reallocation of labor in response to export opportunities. One such study shows that removing export 
taxes and entering a trade agreement with the US contributed to the shift of workers from the informal to the formal sector in Vietnam [8]. Another illustrates similar results for five developing countries, demonstrating that promoting exports can help shift workers from agriculture to higher-paying jobs-jobs that pay enough to compensate workers for the adjustment costs they incur. In this way, export growth contributes to development.

\section{Welfare implications}

From a national welfare point of view, the main issue is how much adjustment costs diminish the welfare gains from free trade. Relatively few studies offer estimates of this nature, but those that do suggest that adjustment costs can lower the welfare gains from trade by $2-3 \%$. These estimates nevertheless suggest that trade can create sufficient gains to compensate those who have to change sectors. For example, one group of researchers has constructed a model that illustrates how the economy adjusts following a rise in imports when adjustment costs are significant [9]. Like earlier models, they show that trade's adverse effects are highly localized but that the gains from trade to consumers are still positive in net. The presence of adjustment costs, however, lowers the welfare gains by $2.5 \%$.

It is important to note that the costs to workers in these models come from the adjustment itself. This means that using trade policy to "correct" for the losses incurred by workers would likely cause a second round of adjustment, which would impose additional costs on workers. Not only would the gains to consumers be lost if tariffs were imposed, but the resulting shift of workers from their current sectors to the now protected sectors would burden them with another round of adjustment costs. Policymakers who impose the tariffs might be surprised to see the lack of employment growth in the protected sectors if workers do not sense that wages in the protected sectors are high enough to cover the associated adjustment costs.

\section{Political implications}

If the benefits of trade outweigh the costs, then voters should support free trade-as long as the losers are compensated. This may seem like a straightforward concept, but even in theory, it can be complicated. The effectiveness and feasibility of compensation depends critically on whether trade is liberalized before or after the compensation plan is established. If compensation is not set up first, then subsequent plans may not be sufficient, because, once the policy is in place, compensation involves a transfer from those who have already received the benefits of trade; however, they may be less likely to contribute after they have received those gains than before. Moreover, informed workers who anticipate being adversely affected by trade will not support free trade in the absence of a sufficient compensation plan. If the lack of support reaches the median voter, then the public will not support free trade.

In addition, net positive welfare gains are not enough to guarantee political support for free trade if the distribution of the gains is not sufficiently equal. Data from the US Trade Adjustment Assistance (TAA) program suggest that redistribution toward those who lose from trade increases the probability that the recipients' representatives would vote for a free trade agreement. In other words, whilst rising inequality reduces popular support 
for trade, a program that effectively compensates the losers could increase its popular support.

\section{Policy responses}

Adjustment costs clearly affect the welfare implications of trade regulation. In particular, the distinction between firm-level and worker-level adjustment costs is important when discussing policies. When firm-level adjustment costs are high, firms are slow to hire and fire workers and, as a result, adjustment to the new environment can be slow. On the other hand, when worker-level adjustment costs are high, workers can incur sustained adverse effects from import competition and will be slow to move to areas and sectors that are growing. Therefore, when designing optimal policy responses, it is important first to understand the relative importance of each cost.

An example of this last point is that, in both developed and developing countries, one of the main issues facing governments is how to respond to the localized adverse effects of trade. In general, these localized effects are the result of relatively high worker-level adjustment costs. Subsidizing firms to hire additional workers would help if these subsidies were translated into higher wages as a way to offset the costs that workers bear from switching jobs or regions. However, such subsidies are generally not the first policy option discussed. Policymakers often begin by regulating trade directly, for example, by raising tariffs, which, as discussed earlier, is likely to burden workers or firms with additional adjustment costs.

\section{Raising tariffs to increase employment}

Policymakers in developing countries are riding a wave of resistance to globalization and are turning toward using tariffs to increase employment-even though empirical research suggests that raising tariffs is not an effective way to help those hurt by trade. For instance, it has been shown that active trade policies are not effective for increasing employment. Recent academic papers have generated similar implications. Using tariffs in developed countries could cause additional adjustment and a sluggish employment response. Furthermore, using tariffs would reduce the welfare gains from international trade that accrue to consumers nationwide. In addition, automation may be a probable response to rising labor and production costs, rather than increased employment. Therefore, economists are generally pessimistic about the use of tariffs to increase employment in developed countries.

In developing countries, however, export promotion can increase labor demand. Finding ways to facilitate exports has been a successful employment strategy for many Asian countries (e.g. Cambodia, Vietnam, Sri Lanka, and Bangladesh). Increasing exports can help bring in low-wage workers from agriculture or the informal sector and, in doing so, generate significant wage gains. For example, one study finds that exporting-sector wages in Cambodia, El Salvador, Honduras, Indonesia, and Madagascar are significantly higher than mean wages (for observationally identical workers), and that wages in agriculture are far below mean wages [10]. The study further shows that expanding exports in developing countries and helping workers move from agriculture to export sectors can result in wage gains of nearly $100 \%$ in some cases. That said, there is a range of other 
labor market policies that could be considered as more direct means of addressing these issues. Helping workers move to high-growth cities and subsidizing training are two key examples.

\section{Direct subsidies}

From an economist's point of view, direct policies are often preferred over indirect ones because the latter can distort the economy in unintended and often unfortunate ways. If there are net welfare benefits from trade that are, however, diluted by adjustment costs, then economists are likely to suggest direct subsidies to reduce those costs. Several recent studies argue that since reallocation is costly and slow, subsidies to offset moving costs are one of the most effective ways to compensate workers adversely affected by trade. One such study finds that giving a full moving subsidy (one that covers $100 \%$ of the mobility costs) can almost completely compensate for the displaced worker's aggregate losses [11]. It is important to acknowledge that different workers have different adjustment costs. In particular, older and skilled workers could still lose, even with subsidies that completely cover average moving costs. This is because it is more difficult for these groups to make up for their loss of job-specific skills. Moreover, a 2015 study shows that older workers especially resist moving and therefore would require larger subsidies to help compensate for their losses [2].

\section{Active labor market policies}

Governments have several additional options to assist workers who are displaced by trade-induced competition, with various forms of training among the most common. The TAA program in the US, for example, includes such training support. Overall, however, the program's results have been mixed, and similar experiences have been found in both developed and developing countries. Active labor market policies in general are not necessarily effective. Few studies found an increase in employment, and the rates of employment, relative to the number of participants, are low. Additionally, these programs can be expensive, which suggests that the returns on investment are low. Employment subsidies were not especially effective either, and the effects did not seem to last in those cases where they were observed. Other programs target job search and matching, but findings of significant effects on employment are quite rare.

One possible reason that these programs are not particularly successful is that they do not target worker-level adjustment costs. Other programs that do target adjustment costs seem to be much more effective. The most promising interventions seem to be those that reduce the costs of obtaining information about jobs. Providing information about other opportunities directly addresses an important source of friction. One recent study notes this specifically: "On the labor supply side, the most promising interventions appear to be ones that help workers access different labor markets, overcoming sectoral and, especially, spatial mismatches..." [12]. Furthermore, providing information is relatively inexpensive, and lack of information has been shown to be a barrier in both developed and developing countries. Even providing a bus ticket in combination with information about job opportunities can induce the kind of mobility that can increase household welfare [13]. 


\section{LIMITATIONS AND GAPS}

The estimation of worker-level adjustment costs is evolving, though still scarce. Looking at different levels of industry aggregation and controlling for permanent unobserved worker heterogeneity may affect the estimates of adjustment costs. Given the current literature, however, it is unlikely that such estimates will be zero, suggesting that this will remain a salient issue. But a better understanding is still needed.

Investigating why workers in some countries seem to be much less mobile between sectors than in other countries is an important direction for future research too. In particular, it is possible that a range of factors contribute to worker-level adjustment costs. Several, such as firm- or industry-specific human capital, health care benefits, pension plans, and the importance of team synergy, have already been identified in the literature. Others, especially policy factors such as the transferability of social insurance, have received less attention.

\section{SUMMARY AND POLICY ADVICE}

Globalization's critics seem to have the upper hand in policy circles on both sides of the Atlantic. Whether discussing Brexit, the US withdrawal from TPP, or the renegotiation of NAFTA in North America, it appears clear that the benefits of trade do not seem to outweigh the costs in the minds of policymakers and voters. As these three examples show, the prevailing policy course in many countries is to raise barriers to trade and disentangle nations from long-standing international agreements.

Diving into the roots of discontent over globalization, it is apparent that certain population groups have suffered from integration and that their losses have been ignored for too long. Communities in developed countries hit by import competition from lowwage countries and communities in developing countries who lost protection due to liberalization suffered similar fates: dislocation, rising unemployment, and the difficult choice of either having to stay in their hometowns and endure dim job prospects or incur the costs of changing industry or location.

The policy measures designed to aid these communities have largely failed. One possible reason is that policymakers did not realize the source of the costs borne by workers and firms. When firms' hiring and firing costs are high, employment is slow to adjust. Large firing costs can have the unintended consequence of making firms less willing to hire workers if they think they will have to retain these workers when hard times return. Reducing hiring and firing costs, usually through labor market deregulation, thus holds the promise of making the labor market more efficient and potentially increasing longterm employment.

However, reducing firing costs at the firm level would also make firing easier. While this would make the labor market more efficient, it is important to understand that the costs imposed on workers from losing their jobs, switching industries, and relocating are generally estimated to be very high. Even the lowest estimates suggest that the cost to workers from switching industries is more than a year's worth of income, and some estimates put that figure higher than six times annual earnings. These costs reduce the net welfare gains from trade which, even when accounting for adjustment costs, are generally found to be positive. 
The real policy question, therefore, is, how to realize the positive gains from trade while minimizing the losses? An effective answer to this question relies on understanding the nature of the relevant adjustment costs and then addressing those costs as specifically as possible. In the case of globalization and worker welfare, the significance of worker-level adjustment costs suggests that direct policies, such as moving subsidies and providing information about opportunities throughout the country, seem to hold the greatest potential for success. These policies have compared well to other active labor market policies and would allow both developed and developing countries to benefit most from international trade.

\section{Acknowledgments}

The author thanks an anonymous referee and the IZA World of Labor editors for many helpful suggestions on earlier drafts.

\section{Competing interests}

The IZA World of Labor project is committed to the IZA Guiding Principles of Research Integrity. The author declares to have observed these principles.

(c) Raymond Robertson 


\section{REFERENCES}

\section{Further reading}

Hollweg, C. H., D. Lederman, D. Rojas, and E. Ruppert Bulmer. Sticky Feet: How Labor Market Frictions Shape the Impact of International Trade on Jobs and Wages. Washington, DC: World Bank, 2014.

Krugman, P. R., M. Obstfeld, and M. J. Melitz. International Economics: Theory and Policy. 10th edition. Boston, MA: Pearson Addison-Wesley, 2014.

\section{Key references}

[1] Artuç, E., S. Chaudhuri, and J. McLaren. "Trade shocks and labor adjustment: A structural empirical approach." American Economic Review 100:3 (2010): 1008-1045.

[2] Artuc, E., D. Lederman, and G. Porto. "A mapping of labor mobility costs in the developing world." Journal of International Economics 95:1 (2015): 28-41.

[3] Dix-Carneiro, R. "Trade liberalization and labor market dynamics." Econometrica 82:3 (2014): 825-885.

[4] Hamermesh, D. S. "Labor demand and the source of adjustment costs." Economic Journal 105:430 (1995): 620-634.

[5] Robertson, R., and D. H. Dutkowsky. "Labor adjustment costs in a destination country: The case of Mexico." Journal of Development Economics 67:1 (2002): 29-54.

[6] Autor, D. H., D. Dorn, and G. H. Hanson. "The China Syndrome: Local labor market effects of import competition in the United States." The American Economic Review 103:6 (2013): 21212168.

[7] Robertson, R. "Relative prices and wage inequality: Evidence from Mexico." Journal of International Economics 64:2 (2004): 387-409.

[8] McCaig, B., and N. Pavcnik. "Moving out of agriculture: Structural change in Viet Nam." In: McMillan, M., D. Rodrik, and C. Sepulveda (eds). Structural Change, Fundamentals, and Growth. Washington, DC: IFPRI, 2017; pp. 81-124.

[9] Caliendo, L., M. Dvorkin, and F. Parro. The Impact of Trade on Labor Market Dynamics. NBER Working Paper No. 21149, May 2015.

[10] Robertson, R., D. Brown, G. Pierre, and L. Sanchez-Puerta (eds). Globalization, Wages, and the Quality of Jobs: Five Country Studies. Washington, DC: World Bank, 2009.

[11] Lake, J., and D. L. Millimet. "An empirical analysis of trade-related redistribution and the political viability of free trade." Journal of International Economics 99 (2016): 156-178.

[12] McKenzie, D. How Effective Are Active Labor Market Policies in Developing Countries? A Critical Review of Recent Evidence. World Bank Policy Research Working Paper No. 8011, March 2017.

[13] Bryan, G., S. Chowdhury, and A. M. Mobarak. "Underinvestment in a profitable technology: The case of seasonal migration in Bangladesh." Econometrica 82:5 (2014): 1671-1748.

\section{Online extras}

The full reference list for this article is available from:

https://wol.iza.org/articles/effects-of-regulating-international-trade-on-firms-and-workers

View the evidence map for this article:

https://wol.iza.org/articles/effects-of-regulating-international-trade-on-firms-and-workers/map 